\title{
A Tribute to Warren Baxter Ballard, 1947-2012
}

\author{
Francis R. COOK
}

Canadian Museum of Nature, P.O. Box 3443, Station D, Ottawa, Ontario K1P 6P4 Canada; email: frcook@ripnet.com

Cook, Francis R. 2014. A tribute to Warren Baxter Ballard, 1947-2012. Canadian Field-Naturalist 128(3): $276-288$.

Warren Baxter Ballard, professor and Bricker Chair in Wildlife Management, Department of Natural Resources Management, Texas Tech University, Lubbock, Texas, lost a battle with pancreatic cancer on 12 January 2012.

He had gained broad research experience in wildlife biology in the boreal forest of Alaska in the northwest and New Brunswick in the east and very different habitats in the southwestern United States. In addition, he had been to New Zealand, Poland, Sweden, and Russia. His extensive publication record spanning 1971 to 2013 included 27 contributions to The Canadian Field-Naturalist covering a variety of vertebrate taxa, including ducks, turkeys, deer, caribou, foxes, wolves, and bears and usually coauthored with students and colleagues. His editorial contributions to journals and other publications were also extensive. As associate editor of The Canadian Field-Naturalist for mammals 1994-2001, 2007-2011, and before and between these periods as an occasional reviewer, he contributed over 280 individual reviews himself or assigned them to graduate students as part of their training.

Warren was born on 28 April 1947, in Boston, Massachusetts. His family moved to Albuquerque, New Mexico, in the early 1950s and Warren attended St. Pius X High School there and, subsequently, enrolled at New Mexico State University. He held numerous summer positions with the New Mexico Department of Game \& Fish, the United States Army Corps of Engineers, the Bureau of Land Management, and the Department of Animal, Range and Wildlife Sciences, New Mexico State University. He obtained a bachelor of science degree in fish and wildlife management in 1969 and a master's in environmental biology from Kansas State University, Manhattan, Kansas, in 1971. His thesis for the latter was entitled, "Importance of social aggression in booming ground hierarchy of greater prairie chickens (Tympanuchus cupido pinnatus)"; his supervisor was Dr. Robert J. Robel.

From 1 August 1971 to 31 July 1973, Warren was a wildlife biologist with the U.S. Fish and Wildlife Service, Tulsa, Oklahoma. From 1 August 1973 to 1 November 1990, he was a research biologist with the Alaska Department of Fish and Game, in Juneau, Homer, Glennallen, Palmer, Anchorage, and Nome, Alaska, but resigned when his application for educational leave was rejected. From 11 January 1990 to 1 January 1992, he

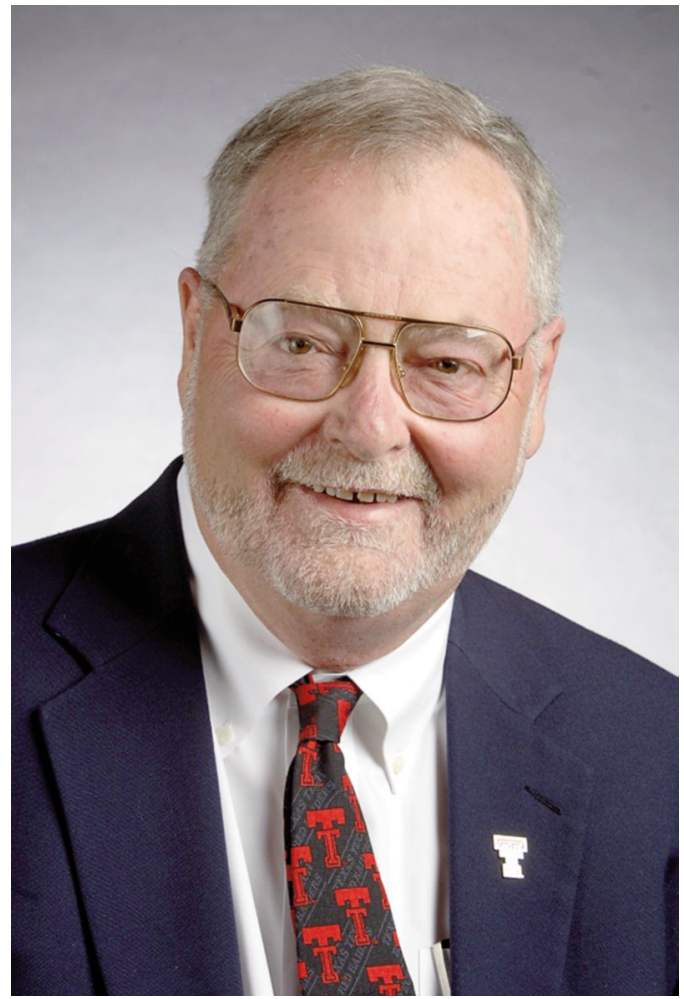

Figure 1: Warren Baxter Ballard, about 2004, at Texas Tech University. Photographer Artie Limmer.

was a research associate at the School of Renewable Natural Resources, University of Arizona, Tucson He received a Ph.D. in Wildlife Science, University of Arizona, in 1993; his dissertation was "Demographics, movements, and predation rates of wolves in northwest Alaska" (supervisor: Dr. Paul R. Krausman).

Briefly, 1-10 January 1992, he was a wildlife research biologist with the U.S. National Park Service, Anchorage, Alaska. From 10 January 1992 to 1 July 1993, he was a senior wildlife ecologist with LGL Alaska Research Associates, Inc., Anchorage, Alaska. This was followed by a position as director and associate professor in the Cooperative Fish and Wildlife Research Unit, University of New Brunswick, Fredericton, New Brunswick, where he stayed until August 1996. 


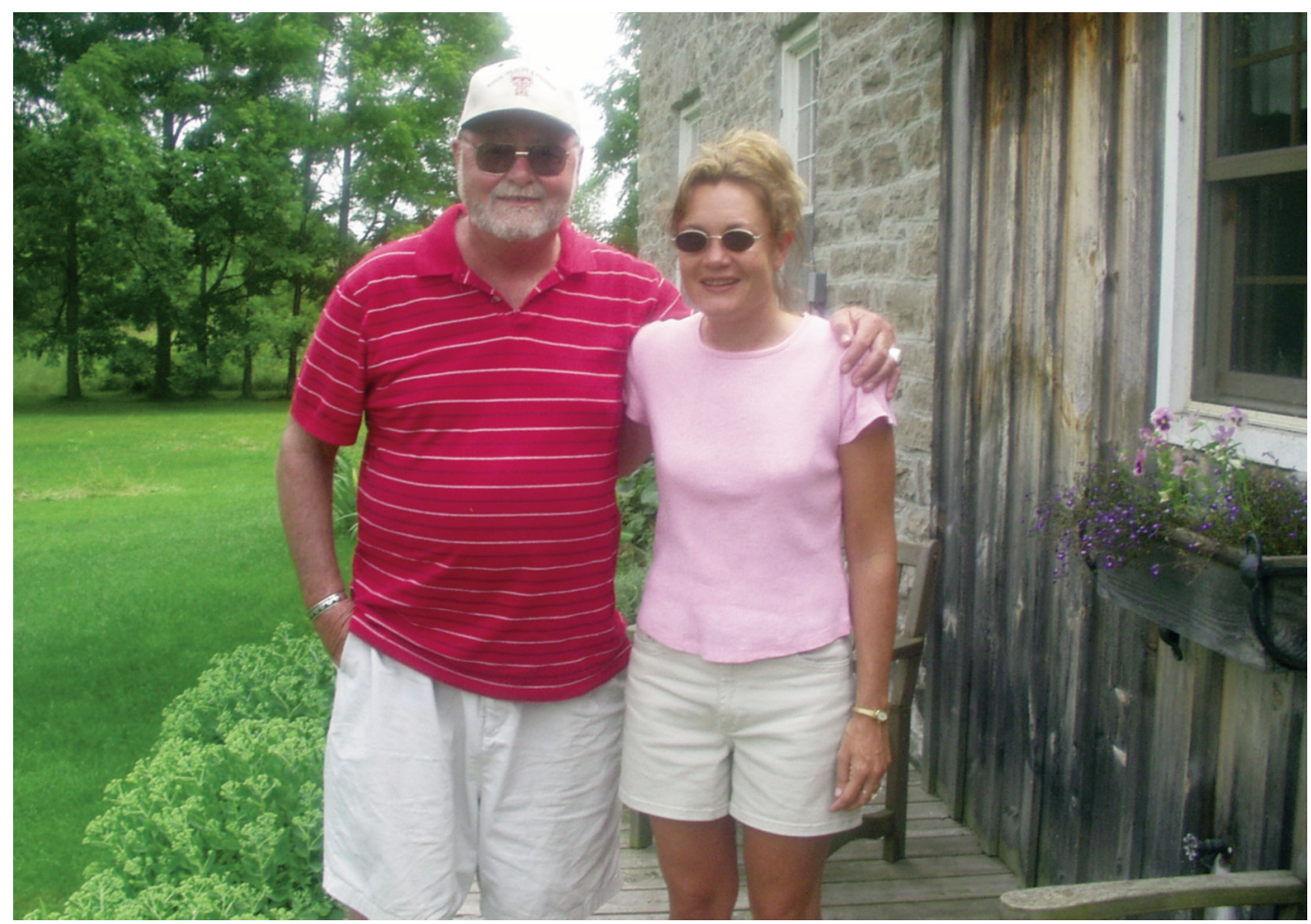

FIGURE 2. Warren Baxter Ballard and Heather Whitlaw on a visit to editor's residence in 2002. Photograph by Francis Cook.

Moving southwest, he spent 1 September 1996 to 1 February 1998 working as research supervisor, Arizona Game and Fish Department, Phoenix, Arizona. In a final move, from 7 January 1998 to 31 August 2003, he was an associate professor in the Department of Natural Resources Management at Texas Tech University, where he became associate chair on 2 July 2002 and was elevated to professor on 1 September 2003. On 13 April 2006, he was appointed to the prestigious Bricker Chair in Wildlife Management, a position he held until his death. In addition, he held appointments as adjunct professor, Faculty of Biology, University of New Brunswick (9 January 1993) adjunct associate professor, School of Renewable Natural Resources, University of Arizona, Tucson (1 October 1996), an adjunct to faculty, Division of Biology, Kansas State University, Manhattan (1 September 1998).

A highly regarded teacher, Warren taught seven courses over 39 terms achieving a 4.5 out of 5 rating in student response. He supervised 44 graduate students (30 at the M.Sc. level and 14 Ph.D.s) as well as two postdoctoral students.

A prolific writer and supervisor, Warren wrote or cowrote an ever-increasing multitude of journal papers, monographs, contributions to books and conference proceedings, and miscellaneous publications, as well as invited presentations and progress reports which were not published.
His editorial contributions were numerous: in addition to his long service as associate editor of The Canadian Field-Naturalist mentioned above, he served as editor in-chief of The Wildlife Society Bulletin (20022005). He was co-editor of Alces (1998-2001); The Moose Call, the newsletter of the North American Moose Conference and Workshop, Canada (19941996); and the Third International Moose Symposium, Soviet Union (1991-1992). He was consulting editor for the University of Alberta Press (1992) and associate editor for Wildlife Monographs (2007, 2004, 1995-1996, and 1989), The Wildlife Society Bulletin (1998-2001), and Alces (1996-1997). He carried out peer reviews for the Canadian Journal of Zoology, the Journal of Mammalogy, the Journal of Wildlife Diseases, The Journal of Wildlife Management, Alces, the Proceedings of Desert Bighorn Sheep Council, the Proceedings of the Second International Wolf Symposium, International Bear Conference, Ecoscience, the Journal of Range Management, Texas Tech University Press, Biological Conservation, Science of the Total Environment, the Texas Journal of Science, and the European Journal of Wildlife Research.

Diverse awards have recognized Warren's many contributions: Distinguished Moose Biologist Award from the North American Moose Conference at St. John's, Newfoundland (1989); an Award for Excellence from the School of Renewable Natural Resources, Uni- 


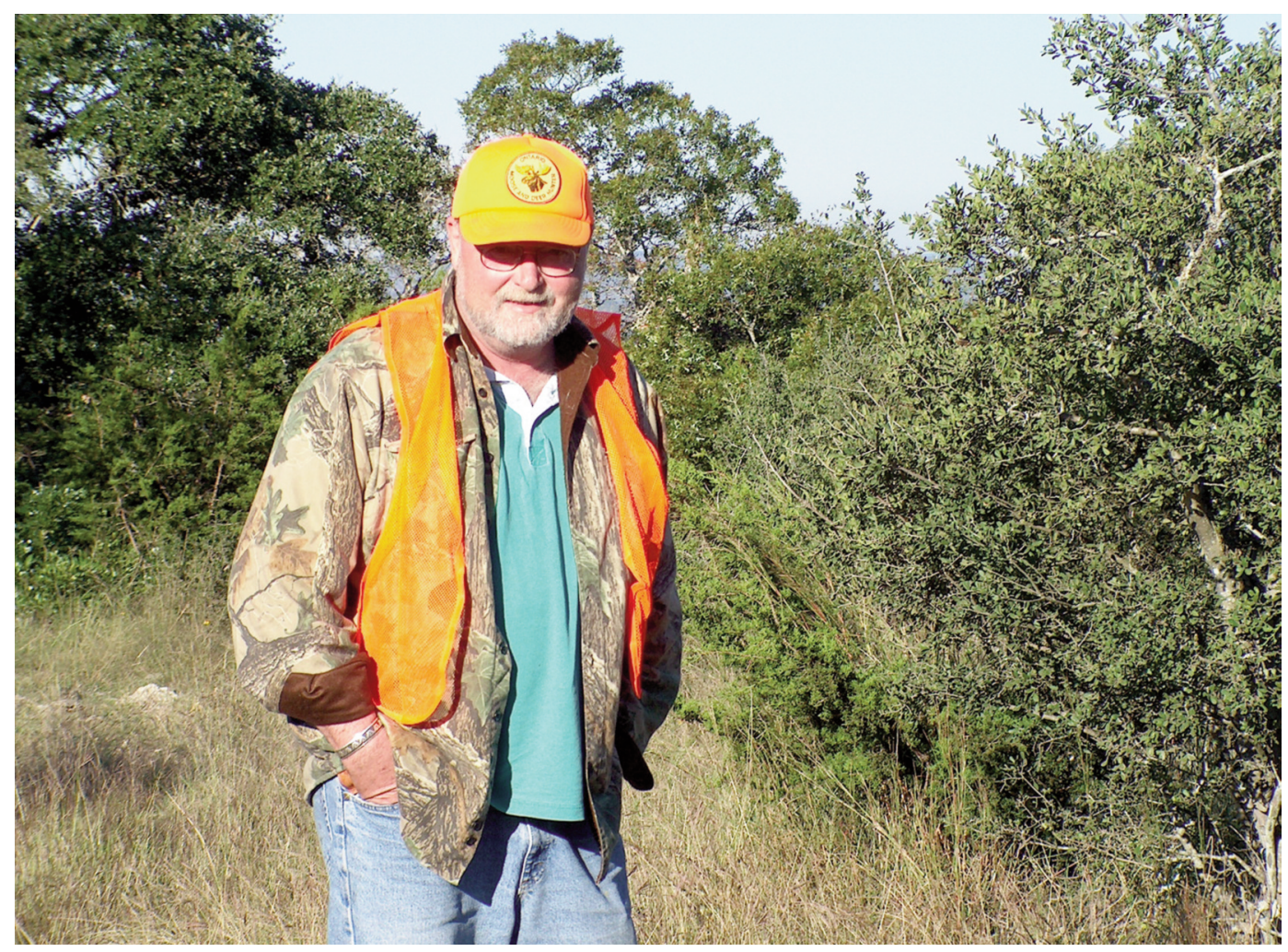

FiguRE 3. Warren Baxter Ballard on a hunting trip in Texas, October 2003. Photograph courtesy Heather Whitelaw.

versity of Arizona, for an outstanding dissertation (1994); the Order of Alces at the 31st North American Moose Conference for service to Alces (1995); a Special Service Award from the University of New Brunswick for contributions to the New Brunswick Cooperative Fish and Wildlife Research Unit from 1993 to 1996 (1996); admission to Sigma Xi honorary research fraternity (1999); the Big 12 Faculty Fellowship from Kansas State University (1999); a Teacher of the Year award from the Range, Wildlife, and Fisheries Club, Texas Tech University (1999); an Outstanding Researcher Award from the College of Agricultural Sciences and Natural Resources, Texas Tech University (2002); Best Article for 2002 from The Wildlife Society in Bismarck, North Dakota, for his paper entitled "Deer-predator relationships: a review of recent North American studies with emphasis on mule and black-tailed deer" (2002); a Special Service Recognition Award from The Wildlife Society, Bismarck, North Dakota (2002); a Chancellors Council Distinguished Research Award from Texas Tech University (2002); the life-time title of TWS Fellow from The Wildlife Society, Madison, Wisconsin (2005); an Outstanding Achievement Award from the Texas Chapter of the Wildlife Society, Beaumont, Texas (2006); and a Best Monograph award from The Wildlife Society for a manuscript entitled "Pathogens, nutritional deficien- cy, and climate influences on a declining moose population" authored by Dennis L. Murray, Eric W. Cox, Warren B. Ballard, Heather A. Whitlaw, Mark S. Lenarz, Thomas W. Custer, Terri Barnett, and Todd K. Fuller, Tucson, Arizona (2007).

Warren was exceptionally active in the science community and professional societies. He held professional membership in The Wildlife Society, the Texas chapter of The Wildlife Society, the American Society of Mammalogists, the Canadian Field-Naturalist, Sigma Xi, and the Southwestern Association of Naturalists. He held numerous positions on committees and served as a consultant to the University of Minnesota, the British Columbia provincial government, LGL Alaska Research Associates, Inc., Entrix Inc., and Revett Silver Mine concerning grizzly bear issues.

Warren had definite views on wildlife research and education, which he put into practice in his teaching, editing, and society involvement, as well as his own research. In his curriculum vitae, he stated,

The purpose of wildlife research is to test hypotheses, develop better techniques, and build a sound database for the management and conservation of wildlife throughout the world. Wildlife research should always use and follow the scientific method. Research should be oriented both towards testing theory and solving technical problems. Dissemination of research results through 
publication is essential to a successful and productive research program.

Education in wildlife and biological sciences should provide students with basic concepts and theories, and equip them with the necessary tools of the trade to be productive biologists. Knowledge of ecological concepts, effective communication skills, statistical expertise, and critical thinking should be stressed at all levels of college education. In addition, recent and current research, as well as management findings and problems should be incorporated into the education process.

On Warren's death, Texas Tech president, Guy Bailey, wrote, "Dr. Ballard was a Texas Tech Horn Professor and the Bricker Chair in Wildlife Management. A Horn professorship is the highest honor a faculty member can receive from the university. Horn professors are a testament to the quality of our academics because they represent the very best of our faculty."

"His legacy lives on in the students, faculty and research projects he touched," said Michael Galyean, interim dean of the College of Agricultural Sciences and Natural Resources.

"Warren was my friend since graduate school, an internationally-recognized research scientist, a major figure in this wildlife program, and an irreplaceable part of our department," said Mark Wallace, chairman of Tech's Department of Natural Resources Management.

On 18 January 2012, Canadian colleague, Graham Forbes, posted a note on a "tribute wall" (Lake Ridge Chapel and Memorial Designers postings): "Warren was very well-liked here at the University of New Brunswick during his time as director of the Wildlife Coop Unit. He initiated some great projects and was valued by all who worked with him. We missed him when he left UNB and it's hard to acknowledge he has passed. I presently occupy his old office and just had a large shot of whisky, in his memory, and his honour. Our thoughts are with Heather."

Dwayne Sabine also posted a message in January: "I was Warren's first grad student. I led one of two deer studies he initiated here in New Brunswick, Canada, and he hired Heather to run the other.... Warren was certainly a positive influence on my career and life. I have fond memories of time spent in the field and at camp with Warren and Heather. He always had great stories at hand, and (unfortunately, perhaps) I may have given him one or two more during his time here (the blindfolded deer that 'got away' comes to mind...)."

Graham Forbes recalled an additional anecdote from Warren's time at the University of New Brunswick (personal communication 18 February 2013): "Warren became 'known' to campus security one autumn when he took his Wildlife Investigation Techniques class on to the rugby field on the edge of campus for some drug immobilization training. The class was target practising with some Cap-Chur rifles $\left(\mathrm{CO}_{2}\right.$-powered for tranquilizing projectiles); in hindsight, it would have been prudent to inform security first!"

Personally, I will miss our many exchanges on manuscript evaluation and on life over 30 years. Our last conversation was shortly before he died - a comparison of our success with walkers. Warren, who had worked efficiently and productively with little interruption over several health setbacks, was ever upbeat and proud of his dexterity with his walker and encouraged me to improve with mine.

Warren was predeceased by his father, Warren Baxter Ballard. He was survived by his mother LaVerne Rosemary Ballard (née Bernat) and his wife, Heather Whitlaw, as well as children Cynthia Bergamo (husband Greg Bergamo), Warren B. Ballard, III (mother Ms. Sheila Sturtz), Laurina Wittig (husband Thomas Wittig), and Raymond Ballard (mother Ms. Tina Cunning); grandchildren Ezra Bergamo, and Blair and Brandon Ballard; mother-in-law, Nan McGhee, fatherin-law, David Whitlaw, sister-in-law, Patricia Whitlaw; and nieces, Elizabeth and Paige Jones. He is fondly remembered by graduate students from the several universities where he had been a staff member as well as by research colleagues and friends from around the world.

\section{Acknowledgements}

Warren's wife and frequent coauthor, Heather Whitlaw, provided Warren's 2007 comprehensive curriculum vitæ, an updated 2012 list of Warren's publications, and a photograph. Roger Applegate searched for the full citation for many incomplete references to publications that appeared after Warren's death. At Texas Tech University, Kristina Woods Butler, Research and Academic Communications, Office of the Vice President for Research, and Norman Martin, College of Agricultural Sciences and Natural Resources, traced the source of Figure 1 and approved its credit and use, respectively. The notice in The Lubbock AvalancheJournal, 13 January 2012, and online comments posted on the Internet guest book of Lake Ridge Chapel and Memorial Designers, 6025 82nd Street, Lubbock, Texas were drawn upon for additional information. Also accessed was the article by Roger D. Applegate and Paul R. Krausman. 2012. Warren B. Ballard, Jr. 1947-2012: A personal tribute. The Wildlife Society 36(1): 4-5. Roger Applegate, Graham J. Forbes, and Heather Whitlaw read earlier drafts of this article and made many appreciated corrections and additions.

\section{Bibliography}

Publications (in chronological order)

Ballard, W. B. 1971. Importance of social aggression in booming ground hierarchy of greater prairie chickens (Tympanuchus cupido pinnatus). M.Sc. Thesis, Kansas State University, Manhattan, Kansas, USA. 90 pages.

Ballard, W. B., and D. Bowen. 1971. Capture methods for upland plovers. Bird Banding. 
Davis, C. A., D. Babb, and W. B. Ballard. 1973. Food habits of mourning doves in the Mesilla Valley of south-central New Mexico, New Mexico State University Agricultural Experiment Station. 8 pages.

Robel, R. J., and W. B. Ballard. 1974. Lek social organization and reproductive success in the greater prairie chicken. American Zoologist 14: 121-128.

Ballard, W. B., and R. J. Robel. 1974. Reproductive importance of dominant male greater prairie chickens. Auk 91: 75-85.

Ballard, W. B. 1978. Status and management of the mountain goat in Alaska. Pages 15-23 in Proceedings of 1st International Mountain Goat Symposium, Kalispell, Montana, February 19, 1977. Edited by W. Samuel and W. G. MacGregor. Fish and Wildlife Branch.

Taylor, K. P., and W. B. Ballard. 1979. Moose movements and habitat use along the Susitna River near Devil's Canyon, Alaska. Proceedings of North American Moose Conference and Workshop 15: 169-186.

Ballard, W. B., H. Merriam, and P. Coppock. 1979. Evaluation of methods utilized to estimate deer harvest in Alaska. Pages 196-206 in Sitka Black-tailed Deer: Proceedings of Conference in Juneau, Alaska. Edited by J. O. C. Wallmo and W. Schoen, Department of Agriculture, Forest Service, Alaska Region.

Ballard, W. B., A. W. Franzmann, K. P. Taylor, T. Spraker, C. C. Schwartz, and R. O. Peterson. 1979. Comparison of techniques utilized to determine moose calf mortality in Alaska. Proceedings of North American Moose Conference and Workshop 15: 362-387.

Ballard, W. B. 1980. Brown bear kills gray wolf. Canadian Field-Naturalist 94: 91.

Ballard, W. B., C. L. Gardner, and S. D. Miller. 1980. Influence of predators on summer movements of moose in south-central Alaska. Proceedings of North American Moose Conference and Workshop 16: 333-359.

Franzmann, A. W., W. B. Ballard, C. C. Schwartz, and T. H. Spraker. 1980. Physiologic and morphometric measurements in neonatal moose and their cows in Alaska. Proceedings of North American Moose Conference and Workshop 16: 362-387.

Ballard, W. B., and R. W. Tobey. 1981. Decreased calf production of moose immobilized with anectine administered from helicopter. Wildlife Society Bulletin 9: 207-209.

Ballard, W. B., T. H. Spraker, and K. P. Taylor. 1981. Causes of neonatal moose calf mortality in southcentral Alaska. Journal of Wildlife Management 45: 335-342.

Ballard, W. B., C. L. Gardner, J. H. Westlund, and S. M. Miller. 1981. Use of mandible versus longbone to evaluate percent marrow fat in moose and caribou. Alces 17: 147-164.

Miller, S. D., and W. B. Ballard. 1982. Homing of transplanted Alaskan brown bears. Journal of Wildlife Management 46: 869-876.

Ballard, W. B., S. D. Miller, and T. H. Spraker. 1982. Home range, daily movements, and reproductive biology of brown bear in southcentral Alaska. Canadian Field-Naturalist 96: $1-5$.

Peterson, R. O., C. C. Schwartz, and W. B. Ballard. 1982. Tooth eruption as an index to population quality in moose. Journal of Wildlife Management 47: 884-888.

Eide, S., and W. B. Ballard. 1982. Apparent case of surplus killing of caribou by gray wolves. Canadian Field-Naturalist 96: 87-88.
Miller, S. D., and W. B. Ballard. 1982. Density and biomass estimates for an interior Alaskan brown bear, Ursus arctos, population. Canadian Field-Naturalist 96: 448-454.

Ballard, W. B., and R. O. Stephenson. 1982. Wolf control — take some and leave some. Alces 18: 726-300.

Ballard, W. B., A. W. Franzmann, and C. L. Gardner. 1982. Comparison and assessment of drugs used to immobilize Alaskan gray wolves (Canis lupus) and wolverine (Gulo gulo) from a helicopter. Journal of Wildlife Diseases 18 : 339-342.

Ballard, W. B. 1982. Gray wolf-brown bear relationships in the Nelchina Basin of southcentral Alaska. Pages 71-80 in Wolves of the World. Edited by F. H. Harrington and P. C. Paquet. Noyes Publications, Park Ridge, New Jersey, USA. 474 pages.

Ballard, W. B., and J. Dau. 1983. Characteristics of gray wolf, Canis lupus, den and rendezvous sites in southcentral Alaska. Canadian Field-Naturalist 97: 299-302.

Ballard, W. B., R. Farnell, and R. O. Stephenson. 1983. Long distance movement by gray wolves. Canadian FieldNaturalist 97: 333.

Franzmann, A. W., C. C. Schwartz, D. C. Johnson, J. B. Faro, and W. B. Ballard. 1984. Immobilization of moose with carfentanil. Alces 20: 259-281.

Tobey, R., and W. B. Ballard. 1985. Increased mortality in gray wolves captured with acepromazine and etorphine hydrochloride in combination. Journal of Wildlife Diseases 21: $188-190$.

Goodwin, E. A., and W. B. Ballard. 1985. Use of tooth cementum for age determination of gray wolves. Journal of Wildlife Management 49: 313-316.

Foster, J. W., and W. B. Ballard. 1985. Radio-telemetry as an aid in the study of wolf den site behavior. Annual Proceedings of the American Association of Zoo Veterinarians. 2 pages.

Whitman, J. S., W. B. Ballard, and C. L. Gardner. 1986. Home range and habitat use by wolverines in southcentral Alaska. Journal of Wildlife Management 50: 460-463.

Gardner, C. L., W. B. Ballard, and J. Jessup. 1986. Long distance movement of a wolverine. Journal of Mammalogy 67: 603 .

Ballard, W. B., S. M. Miller, and J. S. Whitman. 1986. Modelling a southcentral Alaskan moose population. Alces 22: 201-244.

Aumiller, L., and W. B. Ballard. 1986. Documented range extension of the mountain goat, Oreamnos americanus, in Alaska. Canadian Field-Naturalist 100: 560.

Zarnke, R. L., and W. B. Ballard. 1987. Serologic survey for selected microbial pathogens of wolves in Alaska, 19751982. Journal of Wildlife Diseases 23: 77-85.

Miller, S. D., E. F. Becker, and W. B. Ballard. 1987. Density estimates using modified capture-recapture techniques for black and brown bear populations in Alaska. International Conference on Bear Research and Management 7 : 23-35.

Ballard, W. B., and J. S. Whitman. 1987. Marrow fat dynamics in moose calves. Journal of Wildlife Management 51: 66-69.

Ballard, W. B., and D. G. Larsen. 1987. Implications of predator-prey relationships to moose management. Swedish Wildlife, Research Supplement 1: 581-602.

Ballard, W. B., J. S. Whitman, and N. G. Tankersley. 1987. Impact mechanisms of hydroelectric development projects on moose in North America. Swedish Wildlife, Research Supplement 1: 737-740. 
Ballard, W. B., J. S. Whitman, and C. L. Gardner. 1987. Ecology of an exploited wolf population in south-central Alaska. Wildlife Monograph 98. 54 pages.

Bergerud, A. T., and W. B. Ballard. 1988. Wolf predation on caribou: the Nelchina herd case history, a different interpretation. Journal of Wildlife Management 52: 344-357.

Ballard, W. B., A. F. Cunning, and J. S. Whitman. 1988. Hypotheses of impacts on moose due to hydroelectric projects. Alces 24: 34-47.

Ballard, W. B., and A. T. Bergerud. 1988. Wolf population fluctuations in the Nelchina Basin of south-central Alaska: are revisions of previous estimates justified? 3rd North American Caribou Workshop, Fairbanks, Alaska. 2 pages.

Bergerud, A. T., and W. B. Ballard. 1989. Wolf predation on Nelchina caribou: a reply. Journal of Wildlife Management 53: 251-259.

Taylor, Jr., W. P., H. G. Reynolds III, and W. B. Ballard. 1989. Immobilization of grizzly bears with tiletamine hydrochloride and zolazepan hydrochloride. Journal of Wildlife Management 53: 978-981.

Roney, K. E., L. A. Ayres, and W. B. Ballard. 1989. Counting grizzly bears in northwest Alaska. U.S. Department of the Interior Park Science 9: 22-24.

Ballard, W. B., K. E. Roney, L. A. Ayres, and D. N. Larsen. 1990. Estimating grizzly bear density in relation to development and exploitation in northwest Alaska. International Conference on Bear Research and Management 8: 405413.

Ballard, W. B., S. D. Miller, and J. S. Whitman. 1990. Brown and black bear predation on moose in southcentral Alaska. Alces 26: 1-8. Also published in Global Trends in Wildlife Management, 18th International Union of Game Biologists Congress, Jagiellonian University, Krakow, Poland. August, 1987, pages 177-184.

Ballard, W. B., and S. D. Miller. 1990. Effects of reducing brown bear density on moose calf survival in southcentral Alaska. Alces 26: 9-13. Also published in Global Trends in Wildlife Management, 18th International Union of Game Biologists Congress, Jagiellonian University, Krakow, Poland, August 1987. Pages 171-176.

Ballard, W. B., L. A. Ayres, K. E. Roney, and T. H. Spraker. 1991. Immobilization of free-ranging gray wolves with a mixture of tiletamine hydrochloride and zolazepan hydrochloride. Journal of Wildlife Management 55: 71-74.

Ballard, W. B., J. S. Whitman, and D. J. Reed. 1991. Population dynamics of moose in south-central Alaska. Wildlife Monograph 114. 49 pages.

Ballard, W. B., L. A. Ayres, C. L. Gardner, and J. A. Foster. 1991. Den site activity patterns of gray wolves, Canis lupus, in southcentral Alaska. Canadian Field-Naturalist 106: 497504.

Ballard, W. B. 1992. Bear predation on moose: a review of recent North American studies and their implications. Alces 28, Supplement 1: 162-176.

Miller, S. M., and W. B. Ballard. 1992. Analysis of an effort to increase moose calf survivorship by increased hunting of brown bears in south-central Alaska. Wildlife Society Bulletin 20: 445-454.

Ballard, W. B. 1993. Modeled impacts of bear and wolf predation on moose. Alces 28: 79-88.

Ballard, W. B. 1993. Demographics, movements, and predation rates of wolves in northwest Alaska. Ph.D. thesis, University of Arizona, Tucson. 374 pages.
Franzmann, A. W., and W. B. Ballard. 1993. Use of physical and physiological indices for monitoring moose population status - a review. Alces 29: 125-134.

Ballard, W. B., L. A. Ayres, D. J. Reed, S. G. Fancy, and K. E. Roney. 1993. Demography of Noatak grizzly bears in relation to hunting and mining development in northwestern Alaska. U. S. National Park Service Monograph 23. 112 pages.

Ballard, W. B. 1994. Effects of black bear predation on caribou - a review. Alces 30: 25-36.

Van Ballenberghe, V., and W. B. Ballard. 1994. Limitation and regulation of moose populations: the role of predation. Canadian Journal of Zoology 72: 2071-2077.

Forbes, G., P. Chamberland, E. Daigle, and W. B. Ballard. 1994. The lack of problem bear issues in Fundy National Park. Proceedings of 12th Eastern Black Bear Workshop, Knoxville, Tennessee, IBA Publications, Knoxville, Tennessee, USA.

Stephenson, R. O., W. B. Ballard, C. A. Smith, and K. Richardson. 1995. Wolf biology and management in Alaska, 1981-1991. Pages 43-54, in Ecology and Conservation of Wolves in a Changing World. Edited by L. N. Carbyn, S. H. Fritts, and D. R. Seip, Canadian Circumpolar Institute, University of Alberta, Edmonton, Alberta, Canada.

Fancy, S. G., and W. B. Ballard. 1995. Monitoring wolf activity by satellite. Pages 329-334, in Ecology and Conservation of Wolves in a Changing World. Edited by L. N. Carbyn, S. H. Fritts, and D. R. Seip, Canadian Circumpolar Institute, University of Alberta, Edmonton, Alberta, Canada.

Brand, C. J., M. J. Pybus, W. B. Ballard, and R. O. Peterson. 1995. The role of infectious and parasitic diseases in population dynamics of the gray wolf (Canis lupus). Pages 419-430, in Ecology and Conservation of Wolves in a Changing World. Edited by L. N. Carbyn, S. H. Fritts, and D. R. Seip, Canadian Circumpolar Institute, University of Alberta, Edmonton, Alberta, Canada.

Ballard, W. B. 1995. Public attitudes and wildlife science. Northeast Wildlife 51: 63-70.

Ballard, W. B. 1995. Bone marrow fat as an indicator of ungulate condition - how good is it? Alces 31: 105-109.

Ballard, W. B., G. M. Matson, and P. R. Krausman. 1995. Comparison of two methods to age gray wolf (Canis lupus) teeth. Pages 455-460, in Ecology and Conservation of Wolves in a Changing World. Edited by L. N. Carbyn, S. H. Fritts, and D. R. Seip, Canadian Circumpolar Institute, University of Alberta, Edmonton, Alberta, Canada.

Ballard, W. B., D. J. Reed, S. G. Fancy, L. A. Ayres, and P. R. Krausman. 1995. Accuracy, precision, and performance of satellite radio collars for monitoring wolf movements. Pages 461-468, in Ecology and Conservation of Wolves in a Changing World. Edited by L. N. Carbyn, S. H. Fritts, and D. R. Seip, Canadian Circumpolar Institute, University of Alberta, Edmonton, Alberta, Canada.

Ballard, W. B., C. L. Gardner, and D. J. Reed. 1995. Use of line-intercept transects for estimating wolf densities. Pages 469-480, in Ecology and Conservation of Wolves in a Changing World. Edited by L. N. Carbyn, S. H. Fritts, and D. R. Seip, Canadian Circumpolar Institute, University of Alberta, Edmonton, Alberta, Canada.

Ballard, W. B., S. G. Fancy, P. R. Krausman, and W. P. Burger. 1995. Potential applications of satellite telemetry to wildlife studies in remote locations. Pages 566-569 in Integrating People and Wildlife for a Sustainable Future: Proceedings of the first International Wildlife Manage- 
ment Congress. Edited by J. A. Bissonette and P. R. Krausman, The Wildlife Society, Bethesda, Maryland.

Ballard, W. B., and M. A. Cronin. 1995. Arctic Alaska caribou herds in relation to oil field development. Proceedings of 6th Symposium on Impacted Wildlife, Thorne Ecological Institute, Glenwood Springs, Colorado, USA. Pages 35-46.

Lohr, C., W. B. Ballard, and A. Bath. 1996. Attitudes toward gray wolf (Canis lupus) reintroduction to New Brunswick. Wildlife Society Bulletin 24: 414-420.

Lohr, C., and W. B. Ballard. 1996. Historical occurrence of wolves, Canis lupus, in the Maritime Provinces. Canadian Field-Naturalist 110: 607-610.

Pollard, R., W. B. Ballard, M. Cronin, and J. Bryan. 1996. Parasitic insect abundance and microclimate of gravel pads and tundra within the Prudhoe Bay Oil Field, Alaska, in relation to use by caribou, Rangifer tarandus granti. Canadian Field-Naturalist 110: 649-658.

Pollard, R. H., W. B. Ballard, L. E. Noel, and M. A. Cronin. 1996. Summer distribution of caribou, Rangifer tarandus granti, in the area of the Prudhoe Bay Oil Field, 19901994. Canadian Field-Naturalist 110: 659-674.

Balsom, S. E., W. B. Ballard, and H. A. Whitlaw. 1996. Mature coniferous forest as critical moose habitat. Alces 32: 131-140.

Whitlaw, H. A., M. W. Lankester, and W. B. Ballard. 1996. Parelaphostrongylus tenuis in terrestrial gastropods from white-tailed deer winter and summer ranges in northern New Brunswick. Alces 32: 75-83.

Sabine, D. L., A. H. Boer, and W. B. Ballard. 1996. Impacts of habitat fragmentation on pairing success of male Ovenbirds, Seiurus aurocapillus, in southern New Brunswick. Canadian Field-Naturalist 110: 688-693.

Ballard, W. B., P. J. MacQuarrie, A. W. Franzmann, and P. R. Krausman. 1996. Effects of winters on physical condition of moose in Alaska. Alces 32: 51-59.

Ballard, W. B., and P. R. Krausman. 1997. Occurrence of rabies in Alaskan wolves. Journal of Wildlife Diseases 33: 242-245.

Cronin, M. A., B. J. Pierson, S. R. Johnson, L. E. Noel, and W. B. Ballard. 1997. Caribou population density in the Prudhoe Bay Region of Alaska. Journal of Wildlife Research 2: 59-68.

Banfield, E., and W. B. Ballard. 1997. Are corridors justified as a wildlife management tool? Journal of Wildlife Research 2: 182-185.

Cunningham, S. C., R. Engel-Wilson, P. Smith, and W. B. Ballard. 1997. Food habits and nesting characteristics of sympatric mourning and white-winged doves in southcentral Arizona. Journal of Wildlife Research 2: 242-253.

Ballard, W. B., L. A. Ayres, P. R. Krausman, D. J. Reed, and S. G. Fancy. 1997. Ecology of wolves in relation to a migratory caribou herd in northwest Alaska. Wildlife Monograph 135. 47 pages.

Miller, S. D., G. C. White, R. A. Sellers, H. V. Reynolds, J. W. Schoen, K. Titus, V. G. Barnes Jr., R. B. Smith, R.R. Nelson, W. B. Ballard, and C. C. Schwartz. 1997. Brown and black bear density estimation in Alaska using radio-telemetry and replicated mark-resight techniques. Wildlife Monograph 133. 55 pages.

Ballard, W. B., H. A. Whitlaw, D. L. Sabine, R. A. Jenkins, S. J. Young, and G. F. Forbes. 1998. White-tailed deer, Odocoileus virginianus, capture techniques in yarding and non-yarding populations in New Brunswick. Canadian Field-Naturalist 112: 254-261.
Spaulding, R. L., P. R. Krausman and W. B. Ballard. 1998. Summer diet of gray wolves, Canis lupus, in northwestern Alaska. Canadian Field-Naturalist 112: 262-266.

Cronin, M. A., S. C. Amstrup, G. M. Durner, L. E. Noel, and W. B. Ballard. 1998. Caribou distribution during the post-calving period in relation to infrastructure in the Prudhoe Bay oil field, Alaska. Arctic 51: 85-93.

Cronin, M. A., W. B. Ballard, J. D. Bryan, B. J. Pierson, and J. D. McKendrick. 1998. Northern Alaska oil fields and caribou: a commentary. Biological Conservation 83: 195-208

Ballard, W. B., and V. Van Ballenberghe. 1998. Moosepredator relationships: research and management needs. Alces 34: 91-105.

Whitlaw, H. A., W. B. Ballard, D. L. Sabine, S. J. Young, R. A. Jenkins, and G. F. Forbes. 1998. Survival and causespecific mortality rates of adult white-tailed deer in New Brunswick. Journal of Wildlife Management 62: 13351341.

Noel, L. E., R. H. Pollard, W. B. Ballard, and M. A. Cronin. 1998. Activity and use of active gravel pads and tundra by caribou, Rangifer tarandus granti, within the Prudhoe Bay oil field, Alaska. Canadian Field-Naturalist 112: 400-409.

Gipson, P. S., and W. B. Ballard. 1998. Accounts of famous North American wolves, Canis lupus. Canadian FieldNaturalist 112: 724-739.

Gipson, P. S., W. B. Ballard, and R. M. Nowak. 1998. Famous damaging wolves and the credibility of early wildlife literature. Wildlife Society Bulletin 26: 806-816.

Van Ballenberghe, V., and W. B. Ballard. 1998. Population dynamics. Pages 223-245 in Ecology and Management of the North American Moose. Edited by A. W. Franzmann and C. C. Schwartz, Wildlife Management Institute, Washington, D. C., USA (Awarded best book by The Wildlife Society)

Ballard, W. B., and V. Van Ballenberghe. 1998. Predatorprey relationships. Pages 247-273 in Ecology and Management of the North American Moose. Edited by A. W. Franzmann and C. C. Schwartz, Wildlife Management Institute, Washington, D. C. (Awarded best book by The Wildlife Society)

Ballard, W. B., S. S. Rosenstock, and J. C. deVos, Jr. 1998. The effects of artificial water developments on ungulates and large carnivores in the Southwest. Pages 64-105 in Proceedings of Symposium on Environment, Economics, and Legal Issues Related to Rangeland Water Developments, Arizona State University, College of Law, Tempe, Arizona, USA.

deVos, Jr., J. C., W. B. Ballard, and S. S. Rosenstock. 1998. Research design considerations to evaluate efficacy of wildlife water developments. Pages 606-612 in Proceedings of Symposium on Environment, Economics, and Legal Issues Related to Rangeland Water Developments, Arizona State University, College of Law, Tempe, Arizona, USA.

Cunningham, S. C., C. R. Gutavson, L. A. Haynes, and W. B. Ballard. 1999. Diet selection of mountain lions in southeast Arizona. Journal of Range Management 52: 202-207.

Spaulding, R. L., P. R. Krausman, and W. B. Ballard. 1999. Observer bias in scat analyses. Journal of Wildlife Research 2: 128-132.

Rosenstock, S. S., W. B. Ballard, and J. C. deVos, Jr. 1999. Viewpoint: benefits and impacts of wildlife water developments. Journal of Range Management 52: 302-311. 
Ballard, W. B., H. A. Whitlaw, S. J. Young, R. A. Jenkins, and G. F. Forbes. 1999. Predation and survival of whitetailed deer fawns in northcentral New Brunswick. Journal of Wildlife Management 63: 574-579.

Ballard, W. B., M. Edwards, S. G. Fancy, S. Boe, D. J. Reed, and P. R. Krausman. 1999. comparison of VHF and satellite telemetry for estimating wolf territory sizes in northwest Alaska. Wildlife Society Bulletin 26: 823-829.

Forbes, G., D. Johnson, E. Daigle, P. Chamberland, and W. Ballard. 1999. Ecological magnets and black bears in the Greater Fundy Ecosystem. Pages 57-68 in Black Bear Ecology and Management Issues for Atlantic Canadian National Parks: Proceedings of Parks Canada Atlantic Region Black Bear Workshop. Edited by G. Forbes and E. Daigles, Parks Canada, Ottawa, Ontario, Canada.

Forbes, G., P. Chamberland, E. Daigle, and W. Ballard. 1999. The lack of problem bear issues in Fundy National Park. Pages 89-94 in Black Bear Ecology and Management Issues for Atlantic Canadian National Parks: Proceedings of Parks Canada Atlantic Region Black Bear Workshop. Edited by G. Forbes and E. Daigles, Parks Canada, Ottawa, Ontario, Canada.

Daigle, E., G. Forbes, W. Emrich, and W. Ballard. 1999. Black bear den characteristics at forest stand and site scales, New Brunswick. Pages 95-103 in Black Bear Ecology and Management Issues for Atlantic Canadian National Parks: Proceedings of Parks Canada Atlantic Region Black Bear Workshop. Edited by G. Forbes and E. Daigles, Parks Canada, Ottawa, Ontario, Canada.

Rupp, S. P., W. B. Ballard, and M. C. Wallace. 2000. A nationwide evaluation of deer hunter harvest survey techniques. Wildlife Society Bulletin 28: 570-578.

Connor, K. J., W. B. Ballard, T. Dilworth, S. Mahoney, and D. Anions. 2000. Changes in structure of a boreal forest community following intense herbivory by moose. Alces 36: 111-132.

Gipson, P. S., W. B. Ballard, R. M. Nowak, and L. D. Mech. 2000. Accuracy and precision of estimating age of gray wolves by tooth wear. Journal of Wildlife Management 64: 752-758.

Kamler, J. F., K. D. Seyffert, and W. B. Ballard. 2000. Range expansion of the Eurasian Collared-dove in the Texas Panhandle. Texas Ornithological Society Bulletin 33: 23-24

Ballard, W. B., H. A. Whitlaw, B. F. Wakeling, R. L. Brown, J. C. devos Jr., and M. C. Wallace. 2000. Survival of female elk in northern Arizona. Journal of Wildlife Management 64: 500-504.

Ballard, W. B., P. R. Krausman, S. Boe, S. Cunningham, and H. A.Whitlaw. 2000. Short-term response of gray wolves, Canis lupis, to wildfire in northwestern Alaska. Canadian Field-Naturalist 114: 241-247.

Kamler, J. F., W. B. Ballard, and K. Mote. 2000. Aggressive behavior exhibited by a swift fox, Vulpes velox. Canadian Field-Naturalist 114: 506.

Spaulding, R. L., P. R. Krausman, and W. B. Ballard. 2000. Methodology for calculating biomass consumed by gray wolves. Wildlife Society Bulletin 28: 947-950.

Cronin, M. A., H. A. Whitlaw, and W. B. Ballard. 2000. Northern Alaska oil fields and caribou. Wildlife Society Bulletin 28: 919-922.

Ballard, W. B., M. A. Cronin, R. Rodrigues, R. O. Skoog, and R. H. Pollard. 2000. Arctic fox, Alopex lagopus, den densities in the Prudhoe Bay oil field, Alaska. Canadian Field-Naturalist 114: 453-456.
Ballard, W. B., M. A. Cronin, M. D. Robards, and E. H. Follman. 2000. Body sizes, ages, reproductive status, and sex ratios of arctic foxes, Alopex lagopus, in the Prudhoe Bay oil field, Alaska. Canadian Field-Naturalist 114: 493-494.

Ballard, W. B., M. A. Cronin, and H. A. Whitlaw. 2000. Interactions between caribou and oil fields: the Central Arctic Herd Caribou Case History. Pages 85-104 in The Natural History of an Arctic Oil Field Development and the Biota. Edited by J. C. Truett and S. R. Johnson, Academic Press, San Diego, California, USA.

Cronin, M. A., H. A. Whitlaw, and W. B. Ballard. 2001. Addendum to Northern Alaska oil fields and caribou. Wildlife Society Bulletin 29: 764.

Ballard, W. B., E. H. Follman, D. G. Ritter, M. D. Robards, and M. A. Cronin. 2001. Rabies and canine distemper in an arctic fox population in Alaska. Journal of Wildlife Diseases 37: 133-137.

Cunningham, S. C., W. B. Ballard, and H. A. Whitlaw. 2001. Survival and cause-specific mortality rates of a heavily exploited mountain lion population in southeastern Arizona. Southwestern Naturalist 46: 76-80.

Sabine, D., W. B. Ballard, J. Bowman, G. Forbes, and H. A. Whitlaw. 2001. Use of mixedwood stands by wintering white-tailed deer in eastern Canada. Forestry Chronicle 77: 97-103.

Ballard, W. B., D. Lutz, T. W. Keegan, L. H. Carpenter, and J. C. deVos Jr. 2001. Deer-predator relationships: a review of recent North American studies with emphasis on mule and black-tailed deer. Wildlife Society Bulletin 29: 99-115.

Kamler, J. F., W. B. Ballard, and D. A. Swepston. 2001. Range expansion of mule deer in the Texas Panhandle. Southwestern Naturalist 46: 378-379.

Ballard, W. B. 2001. Deer-predator relationships. Pages 52-69 in The role of predator control as a tool in game management: Proceedings of a symposium, 18-19 April 2001, Kerrville, Texas. Edited by T. F. Ginnett and S. E. Henke, Texas Agricultural Research \& Extension Center, San Angelo, Texas, USA.

Kamler, J. F., and W. B. Ballard. 2002. Distribution and taxonomy of red foxes in the western United States. The Wildlife Society Bulletin 30: 370-379.

Ballard, W. B., J. C. deVos Jr., J. F. Kamler, and H. A. Whitlaw. 2002. A need for an integrated radiotemetry database. The Wildlife Society Bulletin 30: 263-264.

Sabine, D., S. F. Morrison, H. A. Whitlaw, W. B. Ballard, G. Forbes, and J. Bowman. 2002. Migration behavior of white-tailed deer under varying winter climate regimes in New Brunswick. Journal of Wildlife Management 66: 718728.

Bowman, J., M. C. Wallace, W. B. Ballard, J. H. Brunjes, M. S. Miller, and J. M. Hellman. 2002. Evaluation of two techniques for attaching radio transmitters to turkey poults. Journal of Field Ornithology 73: 276-280.

Spears, B. L., W. B. Ballard, M. C. Wallace, R. S. Phillips, D. H. Holdstock, J. H. Brunjes, M. Miller, R. D. Applegate, P. S. Gipson, and T. Barnett. 2002. Retention times of miniature radiotransmitters glued to wild turkey poults. The Wildlife Society Bulletin 30: 861-867.

Kamler, J. F., R. M. Lee, J. C. deVos, Jr., W. B. Ballard, and H. A. Whitlaw. 2002. Survival and cougar predation of translocated bighorn sheep in Arizona. Journal of Wildlife Management 66: 1267-1272. 
Marshal, J. P., P. R. Krausman, V. C. Bleich, W. B. Ballard, and J. S. McKeever. 2002. Rainfall, El Nino, and dynamics of mule deer in the Sonoran Desert, California. Journal of Wildlife Management 66: 1283-1289.

Kamler, J. F., W. B. Ballard, R. L. Gilliland, and K. Mote. 2002. Improved trapping methods for swift foxes and sympatric coyotes. The Wildlife Society Bulletin 30: 12621266.

Kamler, J. F., W. B. Ballard, B. Bullock, D. Butler, and R. Ward. 2003. General remains of great horned owl pellets from Union County, New Mexico. New Mexico Journal of Science 43: 68-70.

Kamler, J. F., W. B. Ballard, R. L. Gilliland, P. R. Lemons II, and K. Mote. 2003. Impacts of coyotes on swift foxes in northwestern Texas. Journal of Wildlife Management 67: 317-323.

Kamler, J. F., W. B. Ballard, R. L. Gilliland, and K. Mote. 2003. Spatial relationships between swift foxes and coyotes in northwestern Texas. Canadian Journal of Zoology 81: 168-172.

Kamler, J. F., R. M. Lee, J. C. deVos, Jr., W. B. Ballard, and H. A. Whitlaw. 2003. Mortalities from climbing accidents of translocated bighorn sheep in Arizona. The Southwestern Naturalist: 48: 145-147.

Kamler, J. F., L. A. Green, and W. B. Ballard. 2003. Recent occurrence of black bears in the southwestern Great Plains. The Southwestern Naturalist 48: 303-306.

Ballard, W. B., M. A. Cronin, M. D. Robards, and W. A. Stubblefield. 2003. Heavy metal concentrations of arctic foxes, Alopex lagopus, in the Prudhoe Bay oil field, Alaska. Canadian Field-Naturalist 117: 119-121.

Kamler, J. F., W. B. Ballard, B. R. Helliker, and S. Stiver. 2003. Range expansion of raccoons in the western Utah and eastern Nevada. Western North American Naturalist 63: 406-408.

Kamler, J. F., and W. B. Ballard. 2003. Range expansion of red foxes in eastern Nevada and western Utah. Journal of Arizona-Nevada Academy of Science 36: 18-20.

Kamler, J. F., W. B. Ballard, E. B. Fish, P. R. Lemons, K. Mote, and C. C. Perchellet. 2003. Habitat use, home ranges, and survival of swift foxes in a fragmented landscape: conservation implications. Journal of Mammalogy 84: 989-995.

Avey, J. T., W. B. Ballard, M. C. Wallace, M. H. Humphrey, P. R. Krausman, F. Harwell, and E. B. Fish. 2003. Habitat relationships between sympatric mule and white-tailed deer in south-central Texas. The Southwestern Naturalist 48: 644-653.

Cunningham, S. C., W. B. Ballard, L. M. Monroe, M. J. Rabe, and K. D. Bristow. 2003. Black ear habitat use in burned and unburned areas, central Arizona. Wildlife Society Bulletin 31: 786-792.

Carrera, R., and W. B. Ballard. 2003. Elk distribution in Mexico: a critical review. Wildlife Society Bulletin 31: 1272-1276.

Rodriguez, M. C., P. R. Krausman, W. B. Ballard, C. Villalobos, and W. W. Shaw. 2003. Attitudes of Mexican citizens about wolf translocation in Mexico. Wildlife Society Bulletin 31: 971-979.

Spears, B. L., W. B. Ballard, M. C. Wallace, R. G. Applegate, and P. S. Gipson. 2003. Coyote, Canis latrans - Rio Grande Turkey, Meleagris gallopavo intermedia, interactions. Canadian Field-Naturalist 117: 645-647.
Cronin, M. A., S. P. Haskell, and W. B. Ballard. 2003. The frequency of antlerless female caribou and reindeer in Alaska. Rangifer 23: 67-70.

Spears, B. L., W. J. Peterson, and W. B. Ballard. 2003. Bone marrow fat content of moose from northeastern Minnesota, 1972-2000. Alces 39: 273-285.

Ballard, W. B., D. Lutz, T. W. Keegan, L. H. Carpenter, and J. C. deVos, Jr. 2003. Deer-predator relationships. Pages 177-218 in Mule Deer Conservation: Issues and Management Strategies. Edited by J. C. deVos, M. R. Conover, and N. E. Headrick, Jack H. Berryman Institute Press, Utah State University, Logan, Utah, USA.

Ballard, W. B., L. N. Carbyn, and D. W. Smith. 2003. Wolf interactions with non-prey. Pages 259-271 in Ecology and Conservation of the Wolf. Edited by L. D. Mech and L. Boitani, University of Chicago Press, Chicago, Illinois. USA. (Awarded best book by The Wildlife Society).

Avey, J. T., W. B. Ballard, M. C. Wallace, M. H Humphrey, P. R. Krausman, E. B. Fish, and P. J. Zwank. 2003. Determining habitat variability between sympatric deer species in west-central Texas. Proceedings Western States and Provinces Deer and Elk Workshop.

Lemons, P. R., W. B. Ballard, R. M. Sullivan, and M. A. Sovada. 2003. Den site activity patterns of adult male and female swift foxes, Vulpes velox, in northwestern Texas. Canadian Field-Naturalist 117: 424-429.

Kamler, J. F., and W. B. Ballard. 2003. White color phase of the swift fox, Vulpes velox. Canadian Field-Naturalist 117: 468-469.

McGee, B. K., and W. B. Ballard. 2004. Observations of a bald eagle (Haliaeetus leucocephalus) feeding on prairie dogs (Cynomys ludovicianus) in the northwest Texas panhandle. Bulletin Texas Ornithological Society 37: 14.

Kamler, J. F., and W. B. Ballard. 2004. First record of a long-tailed weasel from the Texas Panhandle. The Prairie Naturalist 32: 141-142.

Kamler, J. F., W. B. Ballard, K. Mote, and R. L. Gilliland. 2004. Coyote (Canis latrans) movements relative to cattle Bos taurus) carcass areas. Western North American Naturalist 64: 53-58.

Kamler, J. F., W. B. Ballard, P. R. Lemons, and K. Mote. 2004. Variation in mating system and group structure in two populations of swift foxes. Animal Behavior 68: 83-88.

Kamler, J. F., W. B. Ballard, E. M. Gese, R. L. Harrison, S. Karkis, and K. Mote. 2004. Adult male emigration and a female-based social organization in swift foxes, Vulpes velox. Animal Behavior 67: 699-702.

Rominger, E. M., H. A. Whitlaw, D. L. Weybright, W. C. Dunn, and W. B. Ballard. 2004. The influence of mountain lion predation on bighorn sheep translocations. Journal of Wildlife Management 68: 993-999.

Lawrence, R. K., S. Demarais, R. A. Relyea, S. P. Haskell, W. B. Ballard, and T. L. Clark. 2004. Desert mule deer survival in southwest Texas. Journal of Wildlife Management 68: 561-569.

Reed, J. E., R . J. Baker, W. B. Ballard, and B. T. Kelly. 2004. Differentiating Mexican gray wolf and coyote scats using DNA analysis. Wildlife Society Bulletin 31: 685692.

Cunningham, S. C., and W. B. Ballard. 2004. Effects of a castrophic wildfire on black bear demographics in central Arizona. Wildlife Society Bulletin 31: 928-937.

Pence, D. B., J. Kamler, and W. Ballard. 2004. Ectoparasites of the swift fox in northwestern Texas. Journal of Wildlife Diseases 40: 543-547. 
Kamler, J. F., W. B. Ballard, and P. S. Gipson. 2004. Occurrence of feral dogs in northwest Texas: an observation. Texas Journal of Agriculture and Natural Resources 15: $75-78$.

Haskell, S. P., and W. B. Ballard. 2004. Factors limiting productivity of the Central Arctic Caribou Herd of Alaska. Rangifer 24: 71-78.

Spears, B. L., W. B. Ballard, M. C. Wallace, R. S. Phillips, D. H. Holdstock, J. H. Brunjes, M. Miller, R. D. Applegate, and P. S. Gipson. 2005. Survival of Rio Grande wild turkey chicks. Journal of Field Ornithology 76: 12-20.

Kamler J. F., W. B. Ballard, P. L. Lemons, R. L. Gilliland, and K. Mote. 2005. Home range and habitat use of coyotes in an area of native prairie, farmland, and CRP fields. American Midland Naturalist 153: 396-404.

Kamler, J. F., W. B. Ballard, R. L. Harrison, and C. G. Schmitt. 2005. Range expansion of red foxes in northwestern Texas and northeastern New Mexico. Southwestern Naturalist 501: 100-101.

Kamler, J. F., W. B. Ballard, E. M. Gese, R. L. Harrison, and S. M. Karki. 2005. Dispersal characteristics of swift foxes. Canadian Journal of Zoology 82: 1-6.

Butler, Matthew J., Andrew P. Teaschner, Warren B. Ballard, and Brady K. McGee. 2005. Commentary: Wildlife Ranching in North America - arguments, issues, and perspectives. Wildlife Society Bulletin 33: 381-389.

Livingston, T. R., P. S. Gipson, W. B. Ballard, D. M. Sanchez, and P. R. Krausmann. 2005. Scat removal: a source of bias in feces related studies. Wildlife Society Bulletin 33: 172-178.

Butler, M. J., M. C. Wallace, W. B. Ballard, and S. DeMaso. 2005. From the field: the relationship of Rio Grande wild turkey distributions to roads. Wildlife Society Bulletin 33: 745-748.

O'Brien, C. S., H. M. Boyd, P. R. Krausman, W. B. Ballard, S. C. Cunningham, and J. C. deVos, Jr. 2005. Influence of wildfire and coyote presence on habitat use by collared peccaries. Wildlife Society Bulletin 33: 865-875.

McGee, B. K., M. J. Butler, M. C. Wallace, W. B. Ballard, and K. L. Nicholson. 2005. From the Field: a comparison of survey techniques for swift fox pups. Wildlife Society Bulletin 33: 1169-1173.

Nicholson, K. L., B. K. McGee, and W. B. Ballard. 2005. Swift fox, Vulpes velox, den located next to a railroad track in northwestern Texas. Canadian Field-Naturalist 119: 584 585 .

Kamler, J. F., and W. B. Ballard. 2006. Ear flashing behavior of black-tailed jackrabbits (Lepus californicus). American Midland Naturalist 155: 390-391.

Cunningham, S. C., L. Kirkendall, and W. B. Ballard. 2006. Gray fox and coyote abundance and diet responses after a wildfire in central Arizona. Western North American Naturalist 66: 169-180.

McGee, B. K., K. L. Nicholson, W. B. Ballard, and M. J. Butler. 2006. Characteristics of swift fox dens in northwest Texas. Western North American Naturalist 66: 239-245.

Brown, A. D., J. H. Brunjes, R. S. Phillips, W. B. Ballard, M. C. Wallace, and R. J. Baker. 2006. Eggshell remains as a noninvasive source of genetic material in wild turkeys (Meleagris gallopavo). Texas Tech University, National Science Research Laboratory, Lubbock, Texas, USA. Occasional paper 257 .

Kamler, J. K., and W. B. Ballard. 2006. Canid diversity in the Texas Panhandle. The Southwestern Naturalist 51: $569-571$.
Haskell, S. P., R. M. Nielson, W. B. Ballard, M. C. Cronin, and T. L. McDonald. 2006. Dynamic responses of calving caribou to oilfields in northern Alaska. Arctic 59: 179-190.

McGee, B. K., M. J. Butler, D. B. Pence, J. L. Alexander, J. B. Nissen, W. B. Ballard, and K. L. Nicholson. 2006. Possible vector dissemination by swift foxes following a plague epizootic in black-tailed prairie dogs in northwest Texas. Journal of Wildlife Diseases 42: 415-420.

Marshal, J. P., P. R. Krausman, V. C. Bleich, S. S. Rosenstock, and W. B. Ballard. 2006. Gradients of forage biomass and ungulate use near wildlife water developments. Wildlife Society Bulletin 34: 620-626.

McGee, B. K., W. B. Ballard, K. L. Nicholson, B. L. Cyper, P. R. Lemons II, and J. F. Kamler. 2006. Effects of artificial escape dens on swift fox populations in northwest Texas. Wildlife Society Bulletin 34: 821-827.

Reed, J. E., W. B. Ballard, P. S. Gipson, B. T. Kelly, P. R. Krausman, M. C. Wallace, and D. B. Wester. 2006. Diets of free-ranging Mexican gray wolves in Arizona and New Mexico. Wildlife Society Bulletin 34: 1127-1133.

Brunjes, K. J., W. B. Ballard, M. H. Humphrey, F. Harwell, N. E. McIntyre, P. R. Krausman, and M. C. Wallace. 2006. Habitat use by sympatric mule and white-tailed deer in Texas. Journal of Wildlife Management 70: 1351-1359.

Holdstock, D. P., M. C. Wallace, W. B. Ballard, J. H. Brunjes, R. S. Phillips, B. L. Spears, S. J. DeMaso, J. D. Jernigan, R. D. Applegate, and P. S. Gipson. 2006. Male Rio Grande turkey survival and movements in the Texas Panhandle and southwestern Kansas. Journal of Wildlife Management 70: 1028-1036.

Nicholson, K. L., W. B. Ballard, B. K. McGee, J. Surles, P. Lemons, and J. F. Kamler. 2006. Swift fox use of blacktailed prairie dog towns in northwest Texas. Journal of Wildlife Management 70: 1659-1666.

Butler, D. A., W. B. Ballard, S. P. Haskell, and M. C. Wallace. 2006. From the field: limitations of thermal infrared imaging for locating neonatal deer in semi-arid shrub communities. Wildlife Society Bulletin: 34: 1458-1462.

McKinney, T., J. C. deVos Jr., W. B. Ballard, and S. R. Boe. 2006. Mountain lion predation of translocated desert bighorn sheep in Arizona. Wildlife Society Bulletin: 34: 12551263.

McGee, B. K., K. L. Nicholson, W. B. Ballard, and M. J. Butler. 2006. Characteristics of swift fox dens in northwest Texas. Western North American Naturalist 66: 239-245.

Butler, M. J., W. B. Ballard, and H. A. Whitlaw. 2006. Physical characteristics, hematology, and serum chemistry of free-ranging gray wolves, Canis lupus, in southcentral Alaska. Canadian Field-Naturalist 120: 205-212.

Murray, D. L., E. W. Cox, W. B. Ballard, H. A. Whitlaw, M. S. Lenarz, T. W. Custer, T. K. Fuller, and T. Barnett. 2006. Pathogens, nutritional deficiency, and climate influences on a declining moose population. Wildlife Monographs 166.30 pages.

Huffman, R. T., M. C. Wallace, W. B. Ballard, G. Hall, R. Houchin, R. D.Applegate, S J. DeMaso, and P. S. Gipson. 2006. Nesting habitat of Rio Grande wild turkeys. Pages 103-111 in Managing Wildlife in the Southwest. Edited by J. W. Cain, III, and P. R. Krausman, Southwest Section of The Wildlife Society, Tucson, Arizona, USA.

Butler, M. J., W. B. Ballard, M. C. Wallace, S. J. Demaso, and R. D. Applegate. 2006. Comparing techniques for counting Rio Grande wild turkeys at winter roosts. Pages 112-117 in Managing Wildlife in the Southwest. Edited 
by J. W. Cain, III, and P. R. Krausman, Southwest Section of The Wildlife Society, Tucson, Arizona, USA.

Spears, B., K. Nicholson, R. Huffman, W. B. Ballard, M. C. Wallace, R. Applegate, and P. Gipson. 2006. Ecology of Rio Grande wild turkeys in southwest Kansas. Kansas Wildlife Bulletin 5. Kansas Wildlife and Parks Department, Pratt, Kansas, USA.

O'Brien, C. S., H. M. Boyd, P. R. Krausman, W. B. Ballard, R. M. Kattnig, S. C. Cunningham, and J. C. deVos, Jr. 2006. Nutritional mule deer forage in burned and unburned interior chaparral. Pages 31-48 in Managing Wildlife in the Southwest. Edited by J. W. Cain III, and P. R. Krausman, Southwest Section of The Wildlife Society. Tucson, Arizona, USA.

Spears, B. L., M. C. Wallace, W. B. Ballard, R. S. Phillips, D. H. Holdstock, J. H. Brunjes, M. Miller, R. D. Applegate, and P. S. Gipson. 2007. Habitat use and survival of pre-flight wild turkey broods. Journal of Wildlife Management 71: 69-81.

Nicholson, K. L., W. B. Ballard, B. K. McGee, and H. A. Whitlaw. 2007. Dispersal and extra-territorial movements of swift foxes (Vulpes velox) in northwestern Texas. Western North American Naturalist 67: 102-108.

Haskell, S. P., and W. Ballard. 2007. Accounting for radiotelemetry signal flux in triangulation point estimation. European Journal of Wildlife Research 53: 204-211.

Haskell, S. P., and W. B. Ballard. 2007. Modeling the Western Arctic Caribou Herd during a positive growth phase: effects of radio-collars and wolves. Journal of Wildlife Management 71:619-627.

Kamler, J. F., W. B. Ballard, M. C. Wallace, R. L. Gilliland, and P. S. Gipson. 2007. Dietary overlap of swift foxes and coyotes in northwestern Texas. American Midland Naturalist: 158 : $140-147$.

Butler, M. J., W. B. Ballard, M. C. Wallace, S. J. DeMaso, and B. K. McGee. 2007. Aerial surveys for estimating wild turkey abundance in the Texas Rolling Plains. Journal of Wildlife Management 71: 1639-1645.

Butler, M. J., W. B. Ballard, M. C. Wallace, and S. J. DeMaso. 2007. Road-based surveys for estimating wild turkey density in the Texas Rolling Plains. Journal of Wildlife Management 71: 1646-1653.

Haskell, S. P., W. B. Ballard, D. A. Butler, N. M. Tatman, M. C. Wallace, C. Kochanny, and P. Alcumbrac. 2007. Observations on capturing and aging deer fawns. Journal of Mammalogy 88: 1482-1487.

Butler, M. J., W. B. Ballard, M. C. Wallace, and S. J. Demaso. 2007. Wild turkey (Meleagris gallopavo) detectability from helicopters and ramifications for estimating abundance. European Journal of Wildlife Research 54: 148-152.

Hall, G. I., M. C. Wallace, W. B. Ballard, D. C. Ruthven III, M. J. Butler, D. P. Holdstock, R. L. Houchin, R. T. Huffman, R. S. Phillips, B. L. Spears, and R. Applegate. 2007. Rio Grande wild turkey habitat selection in the southern Great Plains. Journal of Wildlife Management 71: 2583-2591

Rice, M. B., W. B. Ballard, E. B. Fish, and D. Holdermann. 2007. Predicting private landowner support toward recolonizing Black Bears in the Trans-Pecos Region of Texas. Human Dimensions of Wildlife 12: 405-415.

Haskell, S. P., W. B. Ballard, D. A. Butler, M. C. Wallace, T. R. Stephenson, O. Alcumbrac, and M. H. Humphrey. 2007. Factors affecting birth dates of sympatric deer in west-central Texas. Journal of Mammalogy 89: 448-458.
McGee, B. K., W. B. Ballard, and K. L. Nicholson. 2007. Swift fox, Vulpes velox, den use patterns in northwestern Texas. Canadian Field-Naturalist 121: 71-75.

Holdstock, D. P., M. C. Wallace, W. B. Ballard, J. H. Brunjes, R. S. Phillips, B. L. Spears, S. J. Demaso, J. D. Jernigan, R. D. Applegate, and P. S. Gipson. 2007. Male Rio Grande wild turkey habitat characteristics in the Texas Panhandle and Southwestern Kansas. Ninth Wild Turkey Symposium: 217-230.

Butler, M. J., G. I. Hall, M. C. Wallace, W. B. Ballard, R. S. Phillips, J. H. Brunjes, R. Huffman, R. Houchin, J. Bullock, S. J. DeMasso, R. D. Applegate, and M. Frisbie. 2007. Utility of poult-hen counts to index productivity of Rio Grande wild turkeys. Ninth Wild Turkey Symposium: 159-168.

Brunjes, J. H., W. B. Ballard, M. C. Wallace, R. S. Phillips, D. H. Holdstock, B. L. Spears, M. J. Butler, M. S. Miller, N. E. McIntyre, S. J. DeMasso, R. Applegate, and P.S. Gibson. 2007. Patterns of capture related mortality in Rio Grande wild turkeys. Proceedings of the National Wild Turkey Symposium 9: 75-81.

Phillips, R. S., W. B. Ballard, M. C. Wallace, D. P. Holdstock, B. L. Spears, M. S. Miller, J. H. Brunjes, and S. J. Demaso. 2007. Movement, fidelity and dispersal of Rio Grande wild turkeys in the Texas Panhandle. Ninth Wild Turkey Symposium: 149-158.

Hall, G. I., M. J. Butler, M. C. Wallace, W. B. Ballard, D. P. Holdstock, R. L. Houchin, R. T. Huffman, R. S. Phillips, B. Spears, D. C. Ruthven, and R. Applegate. 2007. Rio Grande wild turkey home range characteristics in the southern Great Plains. Proceedings of Annual Conference of Southeast Association of Fish and Wildlife Agencies: 60: 36-42.

Ranft, R., P. Gipson, W. Ballard, M. Wallace, D. Wester, J. Bonner, R. Huffman, and G. Hall. 2007. Coyote diet in the Texas Panhandle and southwestern Kansas. Proceedings of the North American Prairie Conference 20: 255268.

Mills, B. H., B. D. Vogt, M. L. Sumner, and W. B. Ballard. 2008. Diets of feral emus in the Cross Timbers and Prairies Region of Texas. Southwest Naturalist 53: 385-388.

Carrera, R., J. E. Reed, W. B. Ballard, P. Gipson, B. Kelly, P. Krausman, and M. Wallace. 2008. Comparison of coyote and Mexican wolf diets in the Blue Range Wolf Recovery Area, Arizona and New Mexico. Journal of Wildlife Management 72: 376-381.

Cariappa, C., W. Ballard, S. Breck, A. Piaggio, and M. Newbaum. 2008. Estimating population size of Mexican wolves noninvasively. Ecological Restoration 26: 14-16.

Haskell, S. P., and W. B. Ballard. 2008. Annual re-habituation of calving caribou to oilfields in northern Alaska: implications for expanding development. Canadian Journal of Zoology 86: 627-637.

McRoberts, J. T., M. J. Butler, W. B. Ballard, M. C. Wallace, H. A. Whitlaw and D. A. Haukos. 2008. Aerial surveys for prairie grouse: detectability, disturbance response, and distance sampling. Proceedings of Annual Conference of Southeast Association of Fish and Wildlife Agencies 62: 203. [Abstract].

Nicholson, K. L., W. J. Peterson, and W. B. Ballard. 2008. Comparisons and trends in white-tailed deer, Odocoileus virginianus, in northeastern Minnesota, 1974-1990. Canadian Field-Naturalist 122: 253-261.

McRoberts, J. T., W. B. Ballard, M. J. Butler, H. A. Whitlaw, K. Boydston, and A. H. Swift. 2009. Lesser prairie 
chicken conservation and wind development in the Texas Panhandle: a case for proactive wildlife management. Pages 74-76 in Proceedings of the National Wind Coordinating Collaborative Wind Wildlife Research Meeting VII. October 28-29, 2008, Milwaukee, Wisconsin, USA. Edited by S. Savitt Schwartz, National Wind Coordinating Collaborative, Washington, D. C., USA.

Brunjes, K. J., W. B. Ballard, M. H. Humphrey, F. Harwell, N. E. McIntyre, P. R. Krausman, and M. C. Wallace. 2009. Home range size and overlap of male sympatric mule and white-tailed deer in Texas. Western North American Naturalist 69: 125-130.

Brunjes, Kristina J., Warren B. Ballard, Mary H. Humphrey, Fieldling Harwell, Nancy E. McIntyre, Paul R. Krausman, and Mark C. Wallace. 2009. Home ranges of sympatric mule deer and white-tailed deer in Texas. Southwestern Naturalist 54: 253-260.

Butler, D. J., S. P. Haskell, W. B. Ballard, M. C. Wallace, C. J. Britton, and M. H. Humphreys. 2009. Differences in timing of birth, birthing sites, and bedding sites in sympatric populations of deer. Southwestern Naturalist 54: 261-271.

Merkle, J. A., P. R. Krausman, D. W. Stark, J. K. Oakleaf, and W. B. Ballard. 2009. Summer diet of the Mexican gray wolf (Canis lupus baileyi). Southwestern Naturalist 54: 480-524.

Rice, M. B., W. B. Ballard, E. R. Fish, N. McIntyre, and D. Holdermann. 2009. The importance of accurate landuse/landcover maps for assessing habitat utilization by black bear (Ursus americanus) in the Trans-Pecos region of Texas. Wildlife Biology in Practice 4: 48-56.

Rice, M. B., W. B. Ballard, E. B. Fish, N. E. McIntyre, and D. Holdermann. 2009. Habitat-distribution modeling of a recolonizing black bear, Ursus americanus, population in the Trans-Pecos region of Texas. Canadian Field-Naturalist 123: 246-254.

Tatman, N. M. J. T. McRoberts, W. A. Smith W. B. Ballard, F. P. Kehoe, and T. G. Dilworth. 2009. Nest success and duckling survival of greater scaup, Aythya marila, at Grassy Island, New Brunswick. Canadian Field-Naturalist 123: 323-328.

McRoberts, J. T., W. B. Ballard, M. J. Butler, H. A. Whitlaw, K. Boydston, and A. H. Swift. 2009. Lesser prairie chicken conservation and wind development in the Texas panhandle: a case for proactive e wildlife management. Pages 71-73 in Proceedings of the Wind Wildlife Research Meeting VII. Edited by S. S. Schwartz. National Wind Coordinating Collaborative, 28-29 October 2008, Milwaukee, Wisconsin, USA.

Holt, R. D., M. J. Butler, W. B. Ballard, and C. A. Kukal. 2010. Disturbance of lecking lesser prairie-chickens (Typanuchus pallidicitus) by ring-necked pheasants in (Phasianus colchicus) Hemphill County, Texas. Western North American Naturalist 70: 241-244.

O'Brien, C. S., P. R. Krausman, H. M. Boyd, W. B. Ballard, S. C. Cunningham, and J. C. deVos, Jr. 2010. Influence of coyotes on habitat use by mule deer following a wildfire. California Fish and Game 96: 7-22.

Haskell, S. P., D. A. Butler, W. B. Ballard, M. J. Butler, M. C. Wallace, and M. H. Humphrey. 2010. Deer density estimation in west-central Texas: old versus new ground techniques with mark-resight as a comparative baseline. Proceeding of the Western States and Provinces Deer and Elk Workshop 7: 30-47.
Erxleben, D. R., M. J. Butler, W. B. Ballard, M. C. Wallace, J. B. Hardin, and S. J. DeMaso. 2010. Encounter rates from road-based surveys of Rio Grande wild turkeys in Texas. Journal of Wildlife Management 74: 1134-1140.

Butler, M. J., W. B. Ballard, R. D. Holt, and H. A. Whitlaw. 2010. Sound intensity of booming in lekking lesser prairiechickens. Journal of Wildlife Management 74: 1160-1162.

Ballard, W. B. 2010. Predator-prey relationships. In Biology and Management of White-tailed Deer. Edited by D. Hewitt, CRC Press, Chicago, Illinois.

Mech, L. D., W. Ballard, E. Bangs, and B. Ream. 2010. Restricting wolves risks escapes. BioScience 60: 485-486.

McBride, R. T., A. J. Giordano, and W. B. Ballard. 2010. Diets of jaguars in the transitional Chaco of Paraguay. Bellbird 4: 1-4.

Haskell, S. P., W. B. Ballard, M. C. Wallace, M. H. Humphrey, and D. A. Butler. 2010. Postpartum group cohesion of sympatric deer species in west Texas. Journal of Wildlife Management 74: 1686-1692.

Tatman, N. M., W. B. Ballard, M. C. Wallace, S. P. Haskell, J. deVos, Jr., and O. J. Alcumbrac. 2010. Evaluation of use of vaginal-implant transmitters in mule deer (Odocoileus hemionus). Southwestern Naturalist 56: 247-251.

Cariappa, C. A., J. K. Oakleaf, W. B. Ballard, and S. W. Breck. 2010. A reappraisal of the evidence for regulation of wolf populations. Journal of Wildlife Management 75: 726-730.

Giordano, A. J., and W. B. Ballard. 2010. Noteworthy record of a black howler monkey from the central dry Chaco of Paraguay. Neotropical Primates 17: 74-75.

Walker, R. N., M. C. Wallace, W. B. Ballard, R. S. Phillips, S. L. McKenzie,R. M. Swearingin, and M. Janis. 2010. Lack of cottonwood regeneration in the Southern Great Plains: Implications for Wild Turkeys. Proceedings of the National Wild Turkey Symposium 10: 73-78.

Swearingin, R., M. C. Wallace, W. B. Ballard, M. J. Butler, R. S. Phillips, R. N. Walker, S. L. McKenzie, B. E. Petersen, and D. Ruthven III. 2010. Chronology of Rio Grande wild turkey flocking behavior in the Texas Rolling Plains. Proceedings of the National Wild Turkey Symposium 10: 243-249.

Swearingin, R., M. C. Wallace, W. B. Ballard, M. J. Butler, R. S. Phillips, R. N. Walker, S. L. McKenzie, B. E. Petersen, and D. Ruthven III. 2010. Winter roost characteristics of Rio Grande wild turkeys in the Rolling Plains of Texas. Proceedings of the National Wild Turkey Symposium 10: 251-262.

Wallace, M. C., W. B. Ballard, D. P. Holdstock, and B. Petersen. 2010. Rio Grande wild turkey diets in the Texas Panhandle. Proceedings of the National Wild Turkey Symposium 10: 201-211.

McKenzie, S. L., M. C. Wallace, W. B. Ballard, M. J. Butler, C. Ruthven, and O. Alcumbrac. 2010. Survival, behavior, and physical effects of surgically implanted radiotransmitters on Rio Grande turkey poults. Proceedings of the National Wild Turkey Symposium 10: 111-118.

Phillips, R. S., W. B. Ballard, and M. C. Wallace. 2010. Rio Grande turkey habitat associations during dispersal. Proceedings of the National Wild Turkey Symposium 10: 213-225.

McRoberts, J. T., M. J. Butler, W. B. Ballard, H. A. Whitlaw, and D. A. Haukos. 2011. Detectability of lesser prairie-chicken leks: a comparison of surveys from aircraft. Journal of Wildlife Management 75: 771-778. 
McRoberts, J. T., M. J. Butler, W. B. Ballard, Mark C. Wallace, H. A. Whitlaw, and D. A. Haukos. 2011. Response of lesser prairie-chickens on leks to aerial surveys. Wildlife Society Bulletin 35: 27-31.

Erxleben, D. R., M. J. Butler, W. B. Ballard, M. C. Wallace, M. J. Peterson, N. J. Silvy, W. P. Kuvlesky Jr., D. G. Hewitt, S. J. DeMaso, J. B. Hardin, and M. K. Dominguez-Brazil. 2011. Wild turkey (Meleagris gallopavo) association to roads: implications for distance sampling. European Journal of Wildlife Research 57: 57-65.

Breck, S. W., B. M. Kluever, M. Panasci, J. Oakleaf, T. Johnson, W. Ballard, and L. Howery, and D. L. Bergman. 2011. Domestic calf mortality and producer detection rates in the Mexican wolf recovery area: Implications for livestock management and carnivore compensation scemes. Biological Conservation 144: 930-936.

Panasci, M., W. B. Ballard, S. Breck, D. Rodriguez, L. D. Densmore III, D. B. Wester, and R. J. Baker. 2011. An evaluation of fecal DNA preservation techniques and effects of sample age and diet on genotyping success. Journal of Wildlife Management 75: 1616-1624.

Giordano, A. J., R. Carrera, and W. B. Ballard. 2011. Assessing the credibility of jaguarundi observation using diagnostic criteria and witness qualification. HumanDimensions of Wildlife 16: 360-367.

McDonald, L., T. Stanley, D. Otis, D. Biggins, J. Kuprowski, and W. Ballard. 2011. Recommended methods for range-wide monitoring of the prairie dog in the United States. United States Geologic Survey Special Scientific Publication, Fort Collins, Colorado, USA. In press.

Butler, M. J., B. A. Collier, R. D. Holt, W. B. Ballard, M. J. Peterson, N. J. Silvy, and M. C. Wallace. 2011. Retention of butt-end aluminum bands by wild turkeys. Journal of Wildlife Management 75: 1807-1811.

Schwalm, D. L, W. B. Ballard, E. B. Fish, and H. B. Whitlaw. 2012. Distribution of the swift fox Vulpes velox in Texas Southwestern Naturalist 57: 393-398.

McRoberts, J. T., N. T. Quintana, W. A. Smith, W. B. Ballard, F. P. Kehoe, and T. G. Dilworth. 2012. Greater scaup, Aythya marila, nest site characteristics on Grassy Island, New Brunswick. Canadian Field-Naturalist 126: 15-19.

Conard, J. M., B. K. Sandercock, P. S. Gipson, and W. B. Ballard. 2012. Factors influencing survival of female elk in a harvested population. Journal of Fish and Wildlife Management 3: 199-208.

Flock, B. E., P. S. Gipson, R. D. Applegate, and. W. B. Ballard. 2012. Distance-based habitat associations of north- ern bobwhites in a fescue-dominated landscape in Kansas. Proceedings of the National Quail Symposium 7: 42-51.

Conard, J. M, B. K. Sandercock, P.S. Gipson, and W. B. Ballard. 2012. Factors influencing survival of female elk in a harvested population. Journal of Fish and Wildlife Management 3(2): 199-208

Flock, B. E., P. S. Gipson, R. D. Applegate, and W. B. Ballard. 2012. Distance-based habitat associations of northern bobwhite in southeastern Kansas. Quai-VII: 4251.

McDonald, D. T., W. B. Ballard, M. C. Wallace, W. H. Miller, and J. C. deVos. 2011. Seasonal forage use and availability by pronghorn antelope in north-central Arizona. 24th Biennial Pronghorn Workshop: Partnering for Pronghorn. In press.

\section{Submitted}

Haskell, S. P., W. B. Ballard, M. C. Wallace, P. R. Krausman, M. H. Humphrey, O. J. Alcumbrac, D. A. Butler, and A. M. Haskell. 2011. Population dynamics of sympatric white-tailed and mule deer in Texas. Fauna Monographs.

Tatman, N. M., W. B. Ballard, M. C. Wallace, S. P. Haskell, J. deVos, Jr., O. J. Alcumbrac, C. O'Brien, and P. R. Krausman. 2011. Cause-specific mule deer fawn mortality in central Arizona. Journal of Mammalogy.

Carrera, R., W. Ballard, M. C. Wallace, J. deVos, S. Cunningham, and O. Alcumbrac. 2011. Population dynamics of desert mule deer in central Arizona, 1960-2006. Wildlife Monographs.

Nicholson, K., P .R. Krausman, T. Smith, W. B. Ballard, and T. McKinney. Mountain lion use of urban landscapes in Arizona. Journal of Urban Ecology.

Nicholson, K., P.R. Krausman, T. Smith, W. B. Ballard, and T. McKinney. 2011. Mountain lion habitat selection in Arizona. Journal of Wildlife Management.

Holt, R. D., M. J. Butler, W. B. Ballard, M. C. Wallace, and R. Perez. 2010. Acute effects of radio transmitters in Rio Grande turkeys. Journal of Wildlife Management.

Cariappa, C. A., R. W. Tobey, W. B. Ballard, and S. W. Breck. 2010. Nelchina redux: revisiting the Nelchina caribou-wolf system. Journal of Wildlife Management.

Phillips, R. S., W. B. Ballard, N. E. McIntyre, M. C. Wallace, E. B. Fish, D. K. Holdstock, B. P. Spears, and S. J. DeMaso. 2011. Causal mechanisms behind sex-biased dispersal in Rio Grande wild turkeys. Ecology.

Received 5 February 2013

Accepted 10 March 2014 